http://jmscr.igmpublication.org/home/ ISSN (e)-2347-176x ISSN (p) 2455-0450 crossref DOI: https://dx.doi.org/10.18535/jmscr/v9i5.02

\title{
Prevalence of Vitamin D Deficiency in patients admitted in State Mental Health Hospital: A Cross Sectional Study
}

\author{
Authors \\ Abhilaksh Kango ${ }^{*}$, Anukriti Singh ${ }^{2}$ \\ ${ }^{1}$ Psychiatrist, Himachal Hospital of Mental Health and Rehabilitation, Shimla (HP) \\ ${ }^{2}$ Junior Resident, Deptt. of Anatomy, IGMC, Shimla (HP) \\ *Corresponding Author \\ Dr Abhilaksh Kango
}

Psychiatrist, Himachal Hospital of Mental Health and Rehabilitation, Shimla (HP), 171005

\begin{abstract}
Aim: To evaluate the prevalence of vitamin $D$ and analyse its correlation with various clinical parameters in patients admitted in HHMH \& R, Shimla.

Material and Methods: Cross-sectional analysis was conducted at the HHMH \& R, Shimla. 46 patients in total with a primary psychiatric diagnosis as per ICD 10 were included and assessed for vitamin $D$ levels and was corelated with clinical parameters. Vitamin D deficiency was taken as serum 25-hydroxyvitamin D level $\leq 20 \mathrm{ng} / \mathrm{mL}$.

Results: In our observation $30.4 \%$ patients had deficient and around $41.3 \%$ had insufficient vitamin D levels. It was higher in females (41.7\%) in comparison with males (26.5\%). Prevalence was higher in patients with age more than 30 yrs. (21.7\%), with co-morbidities $(21 \%)$ and psychotic patients. No significant co-relation was found in vitamin D levels and gender, age, psychiatric diagnosis but significant correlation was there with presence of co-morbidities.

Conclusion: Vitamin D deficiency was found higher in psychiatric inpatients. Higher age also came across as a risk factor. Regular screening of which should be done as routine practice and supplementation or lifestyle modifications should be advised as and when required

Keywords: Himachal Hospital of Mental Health and Rehabilitation (HHMH\&R).
\end{abstract}

\section{Introduction}

Vitamin D deficiency is a widespread health issue leading to abnormalities in bone metabolism. Deficiency in vitamin D is associated with many cancers (breast, colon, prostate), cardiovascular disease and autoimmune disorders. ${ }^{1}$ Along with this mental health consequences of vitamin D deficiency are also evident. Depressive symptoms are also ascribed to insufficient vitamin $\mathrm{D}^{2-}$ ${ }^{4}$, cognitive impairment ${ }^{5-7}$, and is also a risk factor for schizophrenia ${ }^{8}$. Various medical problems ${ }^{1}$ such as obesity, diabetes mellitus, and hypertension are also related with vitamin D deficiency, which are fairly common in patients with psychiatric illnesses.

There are various factors which leads to deficiency of vitamin D in person with psychiatric illness. Which can be due to poor diet or less exposure to sunlight or factors like medication, smoking or alcohol which interfere with formation 
of vitamin from sunlight., ${ }^{9,10}$ US Endocrine Society practical guidelines states deficiency of vitamin $\mathrm{D}$ as serum $25-\mathrm{OH} \mathrm{D}<50 \mathrm{nmol} / \mathrm{l}$ or $<20$ $\mathrm{ng} / \mathrm{ml}$ and insufficiency as $25-\mathrm{OH} \mathrm{D}$ between 50 to $75 \mathrm{nmol} / \mathrm{l}(21-29 \mathrm{ng} / \mathrm{ml}){ }^{1}$

A study done on US population reported Vitamin D deficiency prevalence to be $37.5 \%$ in general population. Strong association was seen with various metabolic, neoplastic and immunological disorders. ${ }^{11,12}$

There are studies showing Vitamin D has important role in maintaining mental health, human emotions along with cognitive functions. ${ }^{13,14}$

Studies have shown relationships between vitamin

D deficiency and depressive symptoms or cognitive impairment. Vitamin D deficiency is associated with various neurological disorders like multiple sclerosis, parkinson's disease, alzheimer's disease. $^{15}$

One of the major causes for vitamin D deficiency in patients with mental health problems was low exposure to sunlight [limited outdoor exercise] and reduced vitamin D in food. darker skin people, are more prone to develop Vitamin D deficiency.

\section{Methodology}

We cross-sectionally evaluated the prevalence of deficiency of vitamin D among mentally ill patients.

The below mentioned information was collected from patients: socio-demographic variables, psychiatric diagnosis, serum levels of vitamin D and medical co-morbidities. For the study we collected informed consent from patients/ carer [if the patient is not in a condition to give consent].

To summarize descriptive statistics were used. Based on Vitamin D levels patients were segregated into three clusters : 1) Vit D deficiency if the levels were $<10 \mathrm{ng} / \mathrm{ml}$; 2) Vit D insufficiency if the levels were between 10-29.99 $\mathrm{ng} / \mathrm{ml}$; 3) Adequate vitamin $\mathrm{D}$ if the levels were $\geq 30 \mathrm{ng} / \mathrm{ml}$. The clusters were equated using chisquare tests for gender, age [ $<30$ and $>30$ years], and medical illness [DM, anaemia and hypothyroidism]. The level of significance was kept at $\mathrm{p}<0.05$.

\section{Results}

Our sample comprised of 46 patients, out of which 34 were males and 12 were females. Mean age was found 37.28 years. In study sample $60.9 \%$ patients had psychotic illness whereas $39.1 \%$ had other psychiatric illness.

Table 1: Sociodemographic and clinical variables

\begin{tabular}{|c|c|}
\hline Variables & $\begin{array}{c}\text { Patients } \\
\mathrm{N}=47 \\
\text { Mean (SD)/ Frequency }(\%) \\
\end{array}$ \\
\hline Age in years & $37.28(11)$ \\
\hline $\begin{array}{l}\text { Gender } \\
\text { Male } \\
\text { Female }\end{array}$ & $\begin{array}{l}34(73.9 \%) \\
12(26.1 \%)\end{array}$ \\
\hline $\begin{array}{l}\text { Diagnosis } \\
\text { Schizophrenia } \\
\text { Psychosis unspecified } \\
\text { Others }\end{array}$ & $\begin{array}{l}16(34.8 \%) \\
12(26.1 \%) \\
18(39.1 \%) \\
\end{array}$ \\
\hline $\begin{array}{l}\text { Co-morbidity } \\
\text { Yes } \\
\text { No }\end{array}$ & $\begin{array}{l}15(32.6 \%) \\
31(67.4 \%) \\
\end{array}$ \\
\hline
\end{tabular}

Out of 46 patients $33(71.7 \%)$ patients had vitamin D levels below normal range, out of them $30.4 \%$ had vitamin D deficiency and $41.3 \%$ had vitamin $\mathrm{D}$ insufficiency. In our observation females were more deficient around $41.6 \%$ as compared to males $(26.5 \%)$ but no significant correlation was found in vitamin D deficiency and gender. Also, it was observed that vitamin D deficiency was more in age group $>30$ years (33\%) as compared to $<30$ years group (25\%) but the difference was not significant. Also, it was seen that vitamin D was more deficient in patients with co-morbidities $(66.6 \%)$ in comparison with patients without comorbidities $(12 \%)$ and the difference was statistically significant. Around $32 \%$ patient with psychotic illness were vit D deficient. All above findings are shown in Tables 1 to 6 . 
Table 2: Prevalence of vitamin D deficiency in study population

\begin{tabular}{|l|c|c|}
\hline Vit D levels & Normal & Percent \\
\hline Deficient & 14 & $30.4 \%$ \\
\hline Insufficient & 19 & $41.3 \%$ \\
\hline Normal & 13 & $28.3 \%$ \\
\hline Total & 46 & $100 \%$ \\
\hline
\end{tabular}

Table 3: Distribution of Vit D deficiency and gender among study population

\begin{tabular}{|l|c|c|c|c|c|}
\hline \multirow{2}{*}{ Vit D levels } & \multicolumn{2}{|c|}{ Male } & \multicolumn{2}{c|}{ Female } & \multirow{2}{*}{ P value } \\
\cline { 2 - 5 } & $\mathbf{N}$ & $\mathbf{\%}$ & $\mathbf{N}$ & $\mathbf{\%}$ & \\
\hline Deficient & 09 & 26.5 & 05 & 41.7 & \multirow{2}{*}{0.129} \\
\hline Insufficient & 17 & 50 & 02 & 16.7 & \\
\hline Normal & 08 & 23.5 & 05 & 41.7 & \\
\hline Total & 34 & 100 & 12 & 100 & \\
\hline
\end{tabular}

Table 4: Distribution of Vit D deficiency and age [yrs] among study population

\begin{tabular}{|l|c|c|c|c|c|}
\hline \multirow{2}{*}{ Vit D levels } & \multicolumn{2}{|c|}{ Age $<$ 30 yrs. } & \multicolumn{2}{|c|}{ Age $>$ 30 yrs. } & \multirow{2}{*}{ P value } \\
\cline { 2 - 5 } & $\mathbf{N}$ & $\mathbf{\%}$ & $\mathbf{N}$ & $\mathbf{\%}$ & \\
\hline Deficient & 04 & 25 & 10 & 33 & \multirow{2}{*}{0.677} \\
\hline Insufficient & 08 & 50 & 11 & 36.7 & \\
\hline Normal & 04 & 25 & 09 & 30 & \\
\hline Total & 16 & 100 & 30 & 100 & \\
\hline
\end{tabular}

Table 5: Distribution of Vit D deficiency and co morbidity

\begin{tabular}{|c|c|c|c|c|c|}
\hline \multirow[t]{3}{*}{ Vit D levels } & \multicolumn{4}{|c|}{ Comorbidity } & \multirow[t]{3}{*}{ P value } \\
\hline & \multicolumn{2}{|c|}{ Yes } & \multicolumn{2}{|c|}{ No } & \\
\hline & $\mathbf{N}$ & $\%$ & $\mathbf{N}$ & $\%$ & \\
\hline Deficient & 10 & 66.6 & 04 & 12.9 & $0.001 * *$ \\
\hline Insufficient & 03 & 20 & 16 & 51.6 & \\
\hline Normal & 02 & 13.4 & 11 & 35.5 & \\
\hline Total & 15 & 100 & 31 & 100 & \\
\hline
\end{tabular}

Table 6: Psychiatric diagnosis and Vitamin deficiency

\begin{tabular}{|l|c|c|c|c|c|}
\hline \multirow{2}{*}{ Vit D levels } & \multicolumn{4}{|c|}{ Psychiatric diagnosis } & \multirow{2}{*}{ P value } \\
\cline { 2 - 5 } & \multicolumn{2}{|c|}{ Psychotic illness } & \multicolumn{2}{|c|}{ Others } & \\
\cline { 2 - 5 } & $\mathbf{N}$ & $\mathbf{\%}$ & $\mathbf{N}$ & $\mathbf{\%}$ & \\
\hline Deficient & 10 & 32.3 & 04 & 26.7 & \multirow{2}{*}{0.392} \\
\hline Insufficient & 12 & 38.7 & 07 & 46.7 & \\
\hline Normal & 09 & 29 & 04 & 26.6 & \\
\hline Total & 31 & 100 & 15 & 100 & \\
\hline
\end{tabular}

\section{Discussion}

We found higher prevalence of Vitamin D deficiency, with 33 out of 46 patients in our study group have inadequate vit D levels out of which 14 were deficient. Review article reported that community-based Indian studies done on apparently healthy controls reported a prevalence of Vitamin D levels ranged from 50\%-60\%. Compared to the general population in our observation vitamin D deficiency was higher in patients suffering from mental illness. Our results are also comparable with other studies and indicate that Vitamin D deficiency are much more in patients of psychiatric illness as compared to the general population. ${ }^{16,17}$ It is also seen that it is more prevalent in higher age group and patients with comorbidities. Our study findings mainly emphasis on subjects with psychiatric illness and validate that they should be routinely screened for vitamin $\mathrm{D}$ deficiency in routine evaluation. We may think of giving vitamin $\mathrm{D}$ in routine to the 
patient of mental illness which is more costeffective.

One of the main reasons for improvement in psychiatric symptoms after supplementation are due to therapeutic benefits of Vitamin D. Vitamin $\mathrm{D}$ acts on neuronal receptors which are situated in brain regions that are concerned with human behaviour; it releases neurotrophin from cells which defends brain by anti-oxidant and antiinflammatory defences. ${ }^{18}$

It is recognized that the major reason for vitamin D deficiency are less exposure to sunlight, poor dietary intake, substance use and sedentary life style. ${ }^{11}$ In literature it is seen that patients with severe mental illness smoke tobacco more than general population, run a sedentary lifestyle, and follows poor dietary intake. ${ }^{19} \mathrm{We}$ also found high prevalence of VDID in age group $>30$ years, this suggest this group tend to less exposure to sunlight and poor dietary intake. They are also probably vulnerable group which requires due attention.

Like any other studies our study do have limitations. They are its being cross sectional study, varying psychiatric diagnosis and sociodemographic features.

\section{Conclusion}

Vitamin D deficiency is vastly prevalent in psychiatric patients and it is influenced by age, gender, physical activity and dietary patterns. It is also demonstrated high prevalence of medical comorbidity among vitamin $\mathrm{D}$ deficient population.

\section{References}

1. Holick MF. Vitamin D deficiency. N Engl J Med. 2007;357(3):266-281.

2. Stewart R, Hirani V. Relationship between vitamin $\mathrm{D}$ levels and depressive symptoms in older residents from a national survey population. Psychosom

Med. 2010;72(7):608-612.

3. Ganji V, Milone C, Cody MM, et al. Serum vitamin D concentrations are related to depression in young adult US population: the Third National Health and Nutrition Examination Survey. Int Arch Med. 2010;3(1):29.

4. Milaneschi Y, Shardell M, Corsi AM, et al. Serum 25-hydroxyvitamin D and depressive symptoms in older women and men. J Clin Endocrinol Metab. 2010;95(7):3225-33.

5. Annweiler C, Schott AM, Allali G, et al. Association of vitamin $\mathrm{D}$ deficiency with cognitive impairment in older women: cross-sectional study. Neurology. 2010;74(1):27-32.

6. Buell JS, Dawson-Hughes B, Scott TM, et al. 25-Hydroxyvitamin D, dementia, and cerebrovascular pathology in elders receiving home services. Neurology. 2010;74(1):18-26.

7. Llewellyn DJ, Lang IA, Langa KM, et al. Vitamin D and risk of cognitive decline in elderly persons. Arch Intern Med. 2010; 170(13):1135-41.

8. McGrath JJ, Eyles DW, Pedersen CB, et al. Neonatal vitamin D status and risk of schizophrenia: a population-based casecontrol study. Arch Gen Psychiatry. 2010;67(9):889-94.

9. Gordon CM, DePeter KC, Feldman HA, Grace E, Emans SJ. Prevalence of vitamin D deficiency among healthy adolescents. Arch PediatrAdolesc Med. 2004: 158:5317.

10. Looker AC, Johnson CL, Lacher DA, Pfeiffer CM, Schleicher RL, Sempos CT. Vitamin D status: United States, 20012006. NCHS Data Brief. 2011: 1-8

11. Holick MF, Binkley NC, Bischoff-Ferrari HA, Gordon CM, Hanley DA, Heaney RP, et al. Evaluation, treatment, and prevention of vitamin D deficiency: an Endocrine Society clinical practice guideline. J Clin Endocrinol Metab. 2011: 96:1911-30.

12. Rosen C. Clinical practice. Vitamin D insufficiency. N Engl J Med. 2011: 364:248-54. 
13. Oudshoorn C, Mattace-Raso FU, van der Velde N, Colin EM, van der Cammen TJ. Higher serum vitamin D3 levels are associated with better cognitive test performance in patients with Alzheimer's disease. Dement Geriatr Cogn Disord. 2008: 25:539-43.

14. Kalueff A, Minasyan A, Keisala T, Kuuslahti M, Miettinen S, Tuohimaa P. The vitamin D neuroendocrine system as a target for novel neurotropic drugs. CNS Neurol Disord Drug Targets. 2006: 5:36371.

15. Ganji V, Milone C, Cody MM, McCarty F, Wang YT. Serum vitamin D concentrations are related to depression in young adult US population: the Third National Health and Nutrition Examination Survey. Int Arch Med. 2010: 3:29.

16. Tiangga E, Gowda A, Dent JA. Vitamin D deficiency in psychiatric in-patients and treatment with daily supplements of calcium and ergocalciferol. Psychiatr Bull. 2008:32:390-3.

17. Rosen C. Clinical practice. Vitamin D insufficiency. N Engl J Med. 2011: 364:248-54.

18. Cherniack EP, Troen BR, Florez HJ, Roos BA, Levis S. Some new food for thought: the role of vitamin D in the mental health of older adults. Curr Psychiatry Rep 2009; 11: $12-19$.

19. Sylvia LG, Friedman ES, Kocsis JH, Bernstein E, Brody BD, Kinrys G, et al. Association of exercise with quality of life and mood symptoms in a comparative effectiveness study of bipolar disorder. J Affect Disord. 2013: 151:722-77. 